\title{
Manuscript and Print in the Tangut State: The Case of the Sunzi
}

\author{
Imre Galambos
}

The corpus of Tangut texts discovered among the ruins of Khara-khoto on the territory of the former Tangut state includes a handwritten and a printed version of a translation of the Sunzi bingfa 孫子兵法 (The Art of War of Master Sun; hereafter referred to as Sunzi) followed by a text known as the Sunzi zhuan 孫子傳 (Biography of Master Sun). The two versions are almost identical in wording, confirming that they are two copies of the same translation. Comparing the discrepancies between them, modern scholars concluded that the manuscript must have been a draft to what later became the printed edition and therefore represents an earlier stage in the evolution of the book. In this paper I re-consider the issue of temporal priority of the two versions and advance an argument that it is more likely that the manuscript was copied from the printed edition, even though not necessarily from this particular one. In addition, I intend to draw attention to the complex relationship between manuscript and print culture that existed long after the spread of printing. The materials excavated from Khara-khoto are a unique body of material in this respect, as they provide first-hand evidence to the extensive use of manuscripts in an age when different technologies were already common.

\section{Tangut Contribution to the Development of Printing}

The Tanguts are often evoked in connection with the development of printing technology in China. A particularly important aspect in this regard is the use of moveable type for printing, as the Tanguts were among the first users of this technology. Until the beginning of the 2oth century, however, little was known about their textual culture. The limited number of available sources comprised the stone inscriptions at Juyongguan 居庸關 near the Great Wall about 30 miles northeast of Peking, and several volumes of the Avatamsaka sütra discovered at the Summer Palace amidst the turmoil that followed the suppression of the Boxer Rebellion in 1900. But even the available sources were

(C) IMRE GALAMBOS, 2016 | DOI 10.1163/9789004316256_009

This is an open access chapter distributed under the terms of the Creative Commons Attribution- 
initially not recognized as having been written in Tangut and for some time scholars debated the language and the type of script of these texts. ${ }^{1}$

The discovery of the dead city of Khara-khoto in Inner Mongolia, where a large body of Tangut and Chinese material was found in 1908 changed all this, providing ample evidence for the identity of the strange script. The Russian team, led by the renowned explorer Pjotr K. Kozlov (1863-1935), discovered most of the material inside a stūpa outside the city walls of Khara-khoto and promptly shipped these back to St. Petersburg. Today these are in the collection of the Institute of Oriental Manuscripts of the Russian Academy of Sciences. In 1914, as part of his third expedition to Western China, Sir Aurel Stein (1862-1943) also carried out excavations at the site, collecting a large number of fragments that had been left behind by the Russian expedition. These items were deposited in the British Museum and today they are for the most part in the British Library. ${ }^{2}$ In later years smaller groups of Tangut material have also been found at other sites of the old Tangut state, and texts continue to come to light to this day.

These discoveries provided first-hand sources for the study of Tangut history and culture. Many of the newly found texts were printed but there were also a significant amount of handwritten ones. It is clear that prints and manuscripts circulated concurrently and scribal culture did not disappear with the spread of printing. ${ }^{3}$ In comparison, the Dunhuang corpus, which mostly comprised texts of the $9^{\text {th-1oth }}$ centuries, contains merely a handful of printed material against tens of thousands of manuscripts. This was no doubt due to the fact that the texts from Khara-khoto on average post-dated the Dunhuang manuscripts by about three centuries and by that time printing had become extremely common throughout East Asia. In addition, the composition of the Khara-khoto corpus also attests to the widespread use of printing in this region and, at the same time, to the contribution of the Tanguts to the development of printing.

1 Although in the late 19th and early 2oth centuries Western scholars debated over the identity of the Tangut inscription at Juyongguan, the Qing-dynasty scholar Zhang Shu 張澍 (1781-1847) had already identified it as Tangut almost a century earlier.

2 The British Library was founded in 1973, it inherited the majority of the textual collections from the British Museum, including the Stein collection. A small number of Tangut items have also been sent to India, as Stein's expeditions were partly financed by the Government of India. These are today at the National Museum of India in New Delhi.

3 For a discussion of this phenomenon in the Western context, see Chartier 2007. 
A particularly important aspect in this respect is the use of movable type, which is amply demonstrated by the Khara-khoto material, as well as subsequent discoveries at other sites. ${ }^{4}$ For example, among the texts found in the Baisigou square pagoda 拜寺溝方塔 in Helan county 賀蘭縣 (Ningxia) in 1991 there was a Tangut translation of a Tibetan Tantric text printed with movable type in 6 volumes. ${ }^{5}$ Some believe this to be the earliest extant text produced with wooden movable type and date it to about 1103. ${ }^{6}$ Another wellknown example of a text created with wooden movable type is an edition of the Avatamsaka sūtra, volumes of which are now held at various institutions around the world. ${ }^{7}$ Some studies point out that the earliest specimens of texts printed with clay movable type, a technology we have known about from sporadic references in transmitted Chinese sources, also come from the Tangut state. ${ }^{8}$ All these examples point to the significant role the Tanguts played in the development and spread of printing in East Asia.

\section{Tangut Translations of Chinese Military Texts}

Of special interest for the study of the relationship between manuscript and print cultures are the cases when we have parallel copies of the same text in printed and handwritten form. Quite a few such Buddhist texts survive but there are also examples among the secular material. ${ }^{9}$ One of these is the Tangut translation of the Sunzi bingfa, a treatise on military strategy which

4 Shi and Yasen 1999, 38-54. Zhang Xiumin (2006, 542) identifies four characteristics of texts printed with movable type: (i) the corners of the printed frames around the page do not connect seamlessly; (ii) the ink is uneven across the page; (iii) occasionally individual characters may appear upside down; (iv) there are traces of lines separating columns of characters.

5 Shen Weirong $(2007,93)$ reconstructs the original Tibetan title of this work as dPal kun tu kha sbyor zhes bya ba'i rgyud. For the Tangut books found in the Baisigou square pagoda, as well as the detailed description of other items, see Ningxia wenwu kaogu yanjiusuo 2005.

6 E.g. Niu 1994. We should point out that the text itself is undated and the date of 1103 is suggested by other texts found in the same location.

7 On this text and in particular the copy kept at the Gest Library at Princeton University, see Heijdra and Cao 1992. The authors hypothesize that this copy, which was probably acquired in Peking around 1929, dates to the mid-Yuan period.

8 E.g. Sun 1994 and 2007.

9 One such example is fragments of the preface to the text called Rules of Confession of the Sanctuary of Compassion (Ch: Cibei daochang chanfa 慈悲到場懺法), part of which survives as a block print and a pothi manuscript leaf; see Kepping and Terent'ev-Katanskij 1987. 
enjoyed enormous popularity both in China and the rest of East Asia. ${ }^{10}$ Early copies of the Chinese text survive in Japan and Korea but it was also one of the texts commonly translated into other languages. Thus in addition to the Tangut rendition, there are also several extant Manchu translations. ${ }^{11}$ As to the Tanguts, it is clear that besides translating a wide variety of Chinese texts (e.g. Buddhist sūtras and commentaries, Confucian canonical works, Daoist texts, medical literature, primers), they were also very interested in treatises on military strategy. Among the surviving body of Tangut material there are copies of several Chinese military texts: the Sunzi, the Sunzi zhuan, the Liutao 六鞱 (Six Quivers), the Huangshi gong sanlüe 黃石公三略 (Three Strategies of Master Yellowstone), and the Jiangyuan 將苑 (General's Garden). ${ }^{12}$

Of these works, the Liutao and Huangshi gong sanlüe are woodblock prints but the Jiangyuan is a manuscript. The Sunzi and Sunzi zhuan, however, survive in both printed and handwritten copies, though they only partially overlap and neither of them is complete. Nevertheless, the overlapping portions provide a rare opportunity for comparison. Although there are many more cases of such matching pairs among the Buddhist texts in Tangut, translations of secular texts are understood by modern scholars to be less rigid in adhering to the source text than canonical sūtras and are therefore considered more 'natural' in their wording. ${ }^{13}$ Presumably the reason for this was that in the case of secular texts the comprehensibility and clarity of the translation was more important than adherence to the original wording of a sacred text. Accordingly, works of military strategy may be more 'user-friendly' from the point of view of a Tangut reader than religious literature.

In addition to the main text, the Tangut Sunzi comes with three commentaries, in an unattested combination that does not match any known Chinese edition. In the Chinese tradition only editions with ten or eleven commentaries are known, depending on whether the commentary of Du You 杜佑 $\left(735^{-812}\right)$ is included or not. Since the three commentaries of the Tangut version are also part of the Chinese editions, it is possible that we are dealing with an abridged version originally derived from one of the more extensive known editions. While it is theoretically possible that this was created by a Tangut translator or editor, it is more likely that an edition like this existed in Chinese

10 The Tangut Sunzi was the subject of several studies, including two monographs (Kepping 1979 and Lin 1994) and a several academic articles (Kepping 1977, Nie 1991 and Sun 2010).

11 For an English study of a Manchu translation of the Sunzi, see Mair 2008.

12 For a short introduction to the military works in Tangut translation, see Galambos 2012, $85^{-86}$. For a more detailed study of the Jiangyuan, see Galambos 2011.

13 Kepping 1985, 15-17; Kepping and Gong 2003, 14-16. 
(but was subsequently lost) and the Tangut version is merely a translation of that. After all, several hitherto unknown Chinese texts were discovered among the ruins of Khara-khoto, not to speak of the Tangut translations of Chinese and Tibetan texts. ${ }^{14}$

Another significant difference with Chinese editions is that both the printed and handwritten versions of the Tangut Sunzi come with the Sunzi zhuan appended to their end. The text of the biography comes from the Shiji 史記 (Records of the Historian), China's first dynastic history completed around 100 BC by the historian Sima Qian 司馬遷 (ca. 145-90 BC). The Tangut text at the end of the Sunzi is unmistakably a translation of Master Sun's biography in the Shiji, yet it is not part of known Chinese editions of the Sunzi. Once again, it is possible that the two texts were linked for the first time in Tangut but it is perhaps more likely that the translator was working with an existing Chinese model and translated what was in front of him, rather than compiling an entirely new edition. Nie Hongyin points out that since the Sunzi zhuan is the sole example of a Tangut translation made from an official history, it was probably not extracted independently from the Shiji by a Tangut translator but was instead translated as part of a Chinese edition of the Sunzi in which it already featured. ${ }^{15}$ Moreover, the fact that both printed and handwritten copies of such an unconventional version survived in Tangut translation suggests that this was not an ad hoc arrangement but a relatively popular combination.

A comparison of the two printed and handwritten texts reveals that they are ultimately two versions of the same translation, deriving from a single source. The printed version, however, is not a single book but consists of part of a book bound in a butterfly format and several fragments, which may not belong to the same physical book. Even though it would be desirable to distinguish them, this is only possible through a careful examination of the originals in situ, a task yet to be accomplished. One of the difficulties is that while the bigger part of the extant Sunzi is at the Institute of Oriental Manuscripts in St. Petersburg, there are also some fragments at the British Library in London, making the comparison problematic. ${ }^{16}$ Having said that, even if the surviving

14 E.g. the Tangut translation identified by Shen Weirong as $(2007,93)$ dPal kun tu kha sbyor zhes bya ba'i rgyud (see above).

15 Nie 1991, 267.

16 Two pages of the Sunzi in London (Or.12380/3841-3842) were first identified by Eric Grinstead (1961). In his unpublished manuscript catalogue of the British collection, the Japanese scholar Nishida Tatsuo identifies another fragment (Or.12380/872), although the text on it is rather unclear and it remains to be seen whether it really belongs to the Sunzi. In the facsimile edition published in Shanghai (Xibei di'er minzu xueyuan 2005, v. 1, 296) 
fragments belong to different books, there seem to be no overlaps among them and therefore for the time being the extant bits can be treated as belonging to one text. ${ }^{17}$

The manuscript version is a scroll with 90 lines of text, $17-20$ characters per line. ${ }^{18}$ Except for the last eight lines, the text is written in the cursive script, which would be difficult to read without having a printed version of the same text available. ${ }^{19}$ From the Sunzi itself, only the last 17 lines survive and the bigger part of the scroll is taken up by the Sunzi zhuan (i.e. the biography), which is complete. In line 17, at the text of the Sunzi, we have the title of the preceding work, claiming it to be the Sunzi with three commentaries. ${ }^{20}$ Yet even though we only have the very end of the text, it is clear that the commentaries have not been copied and the scroll only has the main text of the Sunzi. In other words, the title that appears in the manuscript does not fully correspond to the text.

Ksenia B. Kepping points out that the title that appears in the manuscript at the end of the Sunzi is slightly different from the title that appears in the printed version of the same text. ${ }^{21}$ In the manuscript we read $S w a n^{1} t s a^{1} n g a^{1}$ iw a $^{2}$ in $^{1}$ so $^{1}$ mbie (Three commentaries to Master Sun's Art of War), whereas in the printed text the possessive marker $i^{1}$ is absent. This, naturally, does not change the meaning of the title and works just as well grammatically. We should also note that in both versions we have what the Chinese tradition calls an end title (weiti 尾題), that is, a title that appears at the end of a chapter or volume. This is often an abbreviated or more commonly used version of the

it is labelled a Buddhist sūtra (fojing 佛經), which is certainly wrong. But the same facsimile volume identifies further fragments (Or.12380/66o-664) as belonging to the Sunzi. Kychanov $(2005,5)$ also mentions a common phenomenon in Tangut printed text, namely, that the text printed from the same woodblocks appears to have been printed on paper of different size - the leaves could differ in size as much as $5 \mathrm{~cm}$. As an explanation he proposes that these leaves of different size are either fragments of large and small print runs or were printed at different times.

18 A detailed physical description of the manuscript is available in Kepping 1977.

19 Even though the Tangut script itself does not present particular difficulties for reading, the cursive writing is still very hard to read. In their work on Chinese classics in Tangut translation, Kolokolov and Kychanov (1966, 128-133) provide a table of common elements in Tangut cursive script, which among other things shows how the same element can be written in a number of different ways. Eric Grinstead, in his monograph on the Tangut script adds regular-script characters by the side of cursive ones on the facsimile reproduction of the Tangut Xiaojing 孝經 (Classic of Filial Piety) manuscript from St. Petersburg (Grinstead 1972, 300-376).

$20 \quad$ Kepping 1977, 161.

21 Ibid., 161-162. 
title, in contrast with the head title (shouti 首題) that gives the text's full official designation. In surviving medieval manuscripts the two titles at times can be quite different, even though the context makes it clear that they refer to the same text. ${ }^{22}$ In our two versions of the Sunzi, the titles are all end titles and as such they are less rigid than the head titles would be, which may be the reason why they slightly differ. The printed Sunzi has two such end titles, one at the end of the second juan (Kepping 1979, 526) and one at the end of the third juan (ibid., 566). ${ }^{23}$ Interestingly, the former is followed by a note giving a total count of characters in the main text and the commentary.

The printed edition is the same two-fold combination comprising the Sunzi followed by the Sunzi zhuan. In this case the Sunzi includes the three commentaries not only in its title but also in the text. The three commentaries are those by Cao Cao 曹操 $\left(155^{-220}\right)$, Li Quan 李荃 (8th c.) and Du Mu 杜牧 $\left(803^{-852}\right)$, all of which are also part of the ten and eleven commentary editions known from the Chinese tradition. Accordingly, in the printed edition, unlike in the manuscript, the text conforms to the title. In contrast with the scroll, a much larger portion of the Sunzi survives in this edition, although the end of the biography is missing. The overlapping portion includes the last few lines of the Sunzi and most of the biography. Apart from the disparity of including or omitting the three commentaries, the text of the Sunzi matches in the printed and manuscript versions. ${ }^{24}$ The biography shows a number of minor

22 For example, manuscript Or.8210/S.5438 from Dunhuang is a notebook from the 1oth century with Chapter 25 of the Lotus sütra. At the beginning of the manuscript, we find the title Miaofa lianhua jing Guanshiyin pusa pumen pin di ershiwu 妙法蓮華經觀世音菩薩普門品第廿五 (Lotus sūtra, Chapter 25, The universal gateway of Bodhisattva Avalokiteśvara), whereas at the end, Foshuo Guanyin jing yi juan 佛說觀音經一卷 (The sūtra of Bodhisattva Avalokiteśvara, as preached by the Buddha, in one juan). Thus the head and end titles do not match at all, even though we know that this chapter of the Lotus sūtra also commonly circulated separately as a stand-alone sūtra.

23 Kepping $(1970,9)$ is mistaken to claim that the title appears only once in the printed Sunzi.

24 The only difference is two cases where adjacent characters have been accidentally reversed in the manuscript but in both cases this was corrected by a reversal mark commonly seen in both Chinese and Tangut manuscripts (Kepping 1977, 162). Taking into consideration the corrections, these instances do not constitute differences with the printed edition of the text. 
discrepancies, part of the reason for which is no doubt that the overlapping portion is significantly longer (as opposed to the 17 lines of the Sunzi). Kepping lists 39 differences between the two versions, pointing out that the nature of the discrepancies confirms that we are dealing with two versions of the same text. ${ }^{25}$ She argues that the printed text in most cases clarifies and corrects the manuscript, which leads her to conclude that the printed text is an improved version of the manuscript. Finally she voices the possibility that the manuscript may have been the draft for the printed edition. ${ }^{26}$

A problem with this scenario, which Kepping raises herself, is that the manuscript 'draft' does not have the commentaries which are indicated in its title and are in fact present in the printed edition. She thinks that a possible reason for this may have been that the copyist was only interested in the main text of the Sunzi and thus omitted the commentaries, while retaining the original title of the work he was using. ${ }^{27}$ This explanation, however, somewhat contradicts the point about the manuscript being a draft for the printed text. The logical thing would be that a draft of a printed edition would include the commentaries the way they were going to appear in the final edition. Instead, this must be a manuscript version that was obviously copied from a commentated edition (handwritten or printed) that included the three commentaries referred to in the title. Nevertheless, the copyist omitted the commentaries, revealing, as Kepping correctly observed, that he was only interested in the main text and not the commentaries. But I see this as an indication that rather than working on a new edition of the text (especially a commentated one), he copied down the text for his own purposes, perhaps as a private study tool.

We can cite several additional details to support this assumption. One is that the manuscript is written in the cursive hand, which is easier to conceive as being used in a copy intended for personal use, rather than for preparing a printed edition. After all, the process of printing would have still necessitated additional stages, such as writing out a clean copy of the text and then carving this onto woodblocks, and for both of these a standard calligraphy would have been more suitable. When producing a copy for one's own use, however, a hasty hand would have posed no obstacles whatsoever, as the copyist would have had little difficulty reading his own handwriting, while the aesthetic qualities of the text would have been largely irrelevant.

$\begin{array}{ll}25 & \text { Ibid., 163-165. } \\ 26 & \text { Ibid. } \\ 27 & \text { Ibid. }\end{array}$


Similarly, the lack of any kind of formatting in the manuscript that could be considered as anticipating the layout of the printed text is an argument against it representing an intermediary stage on the way to a printed edition. In contrast with this, making a personal copy from an existing book would not have necessitated keeping the layout of the source text, since the point of the exercise would have been to duplicate the content of the text.

Moreover, the Sunzi manuscript is in the form of a scroll. Although the scroll had been the main book form in China and the rest of East Asia up to the latter part of the Tang dynasty, from the second half of the 9th and early 1oth centuries other forms became increasingly common. The Dunhuang manuscripts provide ample evidence for this shift in book form, as around this period we see the appearance of non-orthodox forms such as the butterfly, whirlwind, concertina, pothi and notebook forms, some of which point to a Central Asian influence. Yet the scroll never disappeared but continued to be used alongside other forms. The Khara-khoto texts are significantly later than the Dunhuang manuscripts and likewise come from the periphery of the Chinese domain, where the influence of Central Asian book cultures would have been presumably more pronounced. Consequently, among the surviving body of Tangut texts the scroll is relatively uncommon and most books which are complete enough to show their original form are in butterfly, concertina or notebook formats. The fact that our Sunzi manuscript written in a cursive hand is a scroll may be a sign of it being intended for personal use, in which case binding it properly would have hardly been necessary. It was simply jotted down on a piece of paper and then rolled up.

A point worth noting here is that concertina books were among the most common ones in Khara-khoto. But a concertina is essentially a scroll that is not rolled up but folded into an accordion-like shape. Therefore there is a fine distinction between scroll and concertina and without the outside covers commonly attached to properly bound concertina books, it would be hard to tell them apart. ${ }^{28}$ Fortunately, many of the books were found folded as concertina books and thus we are able to determine precisely their book form. But it is also possible that some of the crumpled fragments assumed by modern conservators to have been scrolls in reality had originally been concertina books. For this reason we cannot rule out the possibility that our manuscript scroll was at one point also in the form of a concertina, which would of course be even less compatible with the idea of having been created as a temporary draft towards a more stable edition. 
As to the differences between the printed text and the manuscript, the discrepancies can also work in the other direction. In this way, what appeared to be a correction of the handwritten draft may be a copying mistake; a 'clarification' of a one-character word with a compound word can simply be a case of accidental omission. The differences listed by Kepping by themselves cannot verify the priority of one version over the other. Contrary to her conclusion, they could just as well support the idea that this was a temporary copy where such minor discrepancies were of little consequence, especially if they did not change the meaning of the text. It is only logical that a military treatise could have been copied for pragmatic purposes which had nothing to do with philological enquiries and other scholarly pursuits. This manuscript may have been one of these personal copies prepared for practical use.

The theory that the manuscript is a draft version of the printed edition also raises some questions with regard to the nature of the entire corpus of texts found in Khara-khoto. First of all, why would an earlier version of a printed text, a copy that functioned as a draft copy for a printed edition, be deposited in a funerary stūpa? We know that the Kozlov expedition found a skeleton in a sitting position inside the so-called library stūpa and it seems reasonable to assume that the stūpa was dedicated to this person. ${ }^{29}$ This parallels the situation of the Dunhuang cave library which initially also held the statue of the monk Hongbian 洪辯 (d. 868), head of the local samgha, and a small niche at the back of the statue enclosed a silk bag with human ashes, presumably those of Hongbian. ${ }^{30}$

The nature of the Dunhuang collection and the reason for its interment have long perplexed scholars. ${ }^{31}$ Sir Aurel Stein, who was the first Westerner to examine the cave, advanced the theory of 'sacred waste,' drawing attention to the existence of a tradition that prohibits the destruction of any writing, no

29 The expedition took the skull of this person back to St. Petersburg, and it was later examined by the anthropologist F. Volkov who concluded that it may have belonged to an older lady who was over fifty years old (Kozlov 1923, 555-556). Based on this supposition, Lev N. Menshikov, who had compiled a descriptive catalogue of Chinese texts from Kharakhoto, advanced the hypothesis that the person buried in the stupa was Empress Luo, widow of the Tangut Emperor Renzong (r. 1139-1193). Kychanov, however, expressed his opinion that this was merely a "romantic hypothesis" which could be refuted if the skull was examined once again. Since then, however, the skull was lost - possibly during the siege of Leningrad.

30 At a later point, in order to create more space for manuscripts, this statue was removed from the library cave (i.e. Cave 17) and moved into the larger anterior cave (i.e. Cave 16) where it stood until recently.

31 See, for example, Rong 1999 and Imaeda 2008. 
matter how small or fragmentary, that has the word of the Buddha. Naturally, this was only one of the possible explanations and not everyone concurred with it. For example the eminent French sinologist Paul Pelliot (1878-1945), who visited the cave a few months after Stein, was a proponent of the theory that the manuscripts were hidden in the cave in order to protect them from an invading force, which he believed to be the Tanguts. ${ }^{32}$ Later on, building on Stein's initial hypothesis, the Japanese scholar Fujieda Akira suggested that the Dunhuang manuscripts were deposited in the library cave because with the spread of printing in the 1oth century the printed books of the Buddhist Canon displaced the handwritten ones, which were thus stored in the cave as sacred waste. ${ }^{33}$ Regardless of which theory is correct, in the case of Khara-khoto neither of these explanations is likely because it is improbable that a stūpa would used either to deposit unwanted scriptures or to hide texts in order to protect them from a hostile invasion. It is evident that Buddhist texts interred in a stūpa must have had a function related to the consecration of the site. Yet even though the bulk of the material found there comprised Buddhist texts, there were also secular ones, including the Sunzi. These must have been connected to the person buried there, either as a personal library or part of a larger collection that person oversaw. In either case, it is hard to explain why a draft copy of the Sunzi would have been preserved as part of this collection. In contrast, it would have been reasonable to deposit in the tomb a personal copy of a text that belonged to the tomb occupant.

\section{Co-existence of Scribal and Printed Cultures}

While none of the above points provide conclusive proof to establish temporal priority between the two versions of Sunzi, when taken together they imply that the manuscript was not a draft for the printed edition but was, rather, itself made from this three-commentary edition - or another similar one (printed or handwritten). Indeed, one cannot avoid noticing that the conjecture that the handwritten version preceded the printed one reflects the commonly held notion that manuscripts generally precede printed texts, an assumption largely based on a modern understanding of the course of the history of the book. According to this understanding, printing technology represented a more advanced stage of evolution and with time it replaced the tedious task

32 For an overview of the various theories proposed to explain the nature of the Dunhuang cave library, see van Schaik and Galambos 2012, 19-28.

33 Fujieda 1973, 128. 
of copying texts by hand. Consequently, as a general principle, manuscripts predate printed books, and if they are from the same period, the manuscript must have served as a temporary means to arrive at the technologically more advanced product: the printed book. A classic example of this view is Prof. Fujieda's above-mentioned explanation for the sealing of the Dunhuang cave library, a convincing argument against which is, for instance, the coexistence of large quantities of manuscripts and prints in the Khara-khoto corpus.

Yet there is undeniably some truth to this model, as before the spread of printing manuscript culture was the main setting in which texts were produced and circulated. The appearance and spread of printing modified this by adding an alternative mode of textual production. Handwritten and printed books, however, were conceived not as opposites in a binary split between old and new technologies but rather as complementing modes of production. By virtue of their very nature, woodblocks faithfully reproduced handwritten originals, consequently print and manuscript did not significantly differ visually. ${ }^{34}$ For that reason it is perhaps better to understand early woodblock printing as an extension of scribal culture, rather than a brand new technology that brought radical changes to the lives of literate communities. If it represented an advancement, it would not have been as obvious to contemporary people as we tend to imagine today. ${ }^{35}$

In fact, even though woodblock printing was already in use in the late $7^{\text {th }}$ century AD, it subsequently fell into disuse and remained largely ignored until the end of the Tang period. ${ }^{36}$ Hence there is certainly a diachronic dimension to the spread of printing, which is also amply demonstrated by the differences

34 Kornicki 2006, 25.

35 We should also point out that although we commonly associate printing with mass production, surviving examples of printed texts do not always support this view, at least not for the medieval period. We usually find only one or two specimens of printed fragments, which would suggest a very low print run. It is of course possible that the reason we do not find more copies of the same print is because most of them perished over time but this would be inconsistent with the fact that numerous copies of the same text are more commonly found in manuscript form. For example, the most popular Buddhist sūtras occur in hundreds of copies each among the Dunhuang manuscripts, many of them produced as part of the same sūtra-copying project.

36 Timothy Barrett (2008) argues that the reason why printing technology did not achieve widespread application during the Tang was that it was too closely associated with the "usurper" Empress Wu Zetian 武則天 (r. 690-705) who had used it for the dissemination of Buddhist texts as part of her quest for legitimacy. Therefore it was only after the end of the dynasty that printing was once again considered a viable option for state-sponsored projects. For additional points and references concerning this topic, see also Barrett 2012. 
in the composition of the Dunhuang and Khara-khoto corpora, as already alluded to above. In fact, the rarity of printed texts in the Dunhuang corpus has been one of the criteria which helped to identify a number of Khara-khoto texts which had been erroneously catalogued in St. Petersburg as being from Dunhuang. ${ }^{37}$ Most items in the small group of printed material discovered in the Dunhuang cave library comprise one-page prayer leaves and calendars, and there are very few longer texts. A famous example of the latter is the 868 copy of the Diamond sütra - the earliest complete dated book in the world - held at the British Library which was, however, brought to Dunhuang from Sichuan. As a result, as soon as it became clear that the St. Petersburg collection had Khara-khoto texts accidentally intermixed among the Dunhuang material, any print with a longer text (i.e. sūtras, commentaries) became an immediate suspect and, indeed, most of them turned out to be from Khara-khoto. Although there is undeniably a certain amount of circularity in excluding printed texts from the Dunhuang corpus by arguing that they are atypical of the corpus, in practice this theory provided a feasible method for isolating items that did not belong there. ${ }^{38}$

Yet printed texts never completely replaced manuscripts which continued to be used until modern times throughout East Asia, especially in the Buddhist context. Sūtra copying for the sake of accruing karmic merit, either by copying them personally or by paying someone else to do so, has been an essential part of Buddhist ritual culture since the early medieval period. But even secular texts continued to be hand-copied in large quantities for various reasons. Discussing the survival of scribal culture in Edo period (1603-1867) Japan, Peter Kornicki argues that manuscripts were used alongside printed editions and that copying printed books by hand was a widespread practice attributable to a range of factors. ${ }^{39}$ People filled notebooks with extracts from books they read, copied religious texts as an act of devotion, created artistic calligraphies of secular texts, or simply copied printed books because those were more expensive, not easily available or even banned. ${ }^{40}$ It is only natural that all of these reasons also played a role in the production of manuscripts in Kharakhoto and other regions of northwestern China.

\footnotetext{
$37 \quad$ Rong 2007.

38 Naturally, this has not been the only criterion for identifying such texts. Other criteria included late dates on dated texts, administrative texts of a particular format, codicological characteristics and the ability to join the fragments with fragments in the Khara-khoto collection. See Rong 2007, 542-543.

39 Kornicki 2006.

40 Ibid., 30-38.
} 
The Khara-khoto material, the texts of which date from the 11th-13th centuries, includes both printed and manuscript books, but without dated colophons or other information that can be linked with particular moments in time it is usually not possible to determine their priority. The Dunhuang manuscripts contain very few printed texts which indicates the rarity of prints at the time; yet there are also manuscripts with colophons and notes that assert that they had been copied from printed texts. For example, in several notebooks of the Diamond sütra (e.g. Pelliot chinois 2876 , Or.8210/S.6762, Or.821o/S.5534, Or.8210/S.5451) a note following the text states that the copy was made "from the true printed text of the Guo family of Xichuan” 西川過家真印本. The wording slightly differs in the different copies but they all claim to have been copied from the same printed edition of the Diamond sütra. One of the manuscripts is dated to 905 and presumably the other ones were also written around the same period. This demonstrates how even among the Dunhuang manuscripts we find examples of manuscripts copied from printed editions, showing that the temporal priority of manuscripts vs. prints cannot always be taken for granted.

A telling example of the symbiotic relationship between manuscript and print is found on one of the pages of the printed edition of the Tangut Sunzi zhuan, where the top of the page is missing with the first two characters of each row. Accordingly, the lines only have 11 characters instead of the 13 on adjacent pages. As a means of restoring the text, someone wrote the missing Tangut characters by hand, thereby rectifying the problem. Although it is not entirely visible on the available reproductions, it seems that the paper itself is intact which would mean that the missing part of the text is a printing error. Perhaps the woodblock broke off and all prints made from it had this part missing. ${ }^{41}$ While the restoration of missing printed text in this manner is a phenomenon well attested in later print culture in both China and the West, the missing text was almost always added by subsequent owners or users of the text much later, often in the modern period. In our case, however, the handwritten characters were added before the stūpa in Khara-khoto was closed, possibly immediately after the book was produced. Consequently, this page is one of the earliest examples of such mixing of printed and handwritten text.

There are also some cases of printed images attached to the beginning of concertina manuscripts of Buddhist sūtras. Manuscript Inv. No. 2208 from the

41 Another possibility is that the damage occurred to the printed page and the handwritten additions are on an extra sheet of paper used by a medieval conservator. Naturally, this could be easily verified by examining the original page in St. Petersburg. 
St. Petersburg collection, for example, is volume (juan) 1 of the Tangut translation of the Mahāprajñāpāramitā sūtra, which is by far the most common text in the Tangut corpus from Khara-khoto. This manuscript begins with a woodblock printed image of the Buddha preaching to his disciples. The exact same illustration also appears in volume 160 of the Mahāprajñāpāramitā sūtra (Inv. No. 1763), which suggests that all volumes of this copy of the sūtra may have begun with the same image. In turn, this also confirms that the image was not arbitrary but had a significance for the particular sūtra. To cite another example, the concertina manuscript Inv. No. 150 of the Dirghâgama sūtra also has a printed illustration at the beginning, showing the Buddha preaching to the multitudes. ${ }^{42}$ Furthermore, woodblock printed books are sometimes recycled in the cover of concertina manuscripts, as it is the case in manuscript Inv. No. 1786 (St. Petersburg), a handwritten copy of volume 195 of the Mahāprajñāpāramitā sütra. The cover is assembled from recycled paper in a way that the pages are turned inwards. Yet the text shows through and it is visible that the pages used to belong to a printed dictionary of some sort.

\section{5}

\section{Conclusions}

This paper examined the relationship between two surviving versions of the Tangut translation of a text comprising the Sunzi and the Sunzi zhuan. The pairing of these two otherwise distinct texts may have been part of a now lost Chinese edition which was available in the Tangut state. The two Tangut versions clearly represent the same translation as the discrepancies between them are minor and for the most part inconsequential. Yet one of them is a manuscript and the other a print. Having compared these against each other, modern scholars came to the conclusion that the print post-dated the manuscript, as it corrected and supplemented the manuscript in a number of instances. Accordingly, the handwritten copy was assumed to have functioned as a draft copy in the process of producing the printed edition. As a result of my own analysis of the two versions, however, I argue that the handwritten copy was probably made from a printed edition and thus should be considered later.

To be sure, in itself the question which version was earlier is of minor import and may seem like a trivial pursuit. Yet this particular case helps to reconsider some of our assumptions concerning the relationship between manuscript

42 Colour photographs of these manuscripts appear at the beginning of the facsimile editions of Khara-khoto materials in Russian collections, published by the Chinese publisher Shanghai guji chubanshe (vols. 15 and 17). 
and print in the medieval period. It questions the common, typically unstated, assumption that manuscripts predate printed texts, a belief ultimately stemming from a linear view of the evolution of book culture. By examining the two versions of the Tangut Sunzi and drawing on evidence from other texts found in Dunhuang and Khara-khoto, I attempted to uncover the faults in this scenario and demonstrate that manuscripts continued to be used even after printing technology became widespread. Woodblock printing was not considered a radically new technology that would render older forms of book production obsolete. In fact, scribal and printed cultures co-existed for centuries, as is amply evidenced by the corpus of Chinese, Tangut and Tibetan texts found in Khara-khoto. Even the much earlier Dunhuang materials include manuscripts made from printed editions, confirming that without other supportive evidence manuscripts should not automatically be judged to be earlier than printed texts.

Finally, the case presented here is an example of the significance of the materiality of excavated texts. Former research has given little attention to this aspect of the Tangut Sunzi (or Tangut material in general), concentrating on textual and linguistic issues, even though the physical form of these manuscripts and prints affords important clues to their production, use and relationship. Including these parameters in our enquiry enables us to uncover a host of additional information which in turn has implications for the interpreting the social and cultural circumstances of the texts in their original milieu. My intention was to call attention to the possibilities inherent in such an approach for furthering our understanding of Tangut texts, be they handwritten or printed.

\section{References}

Barrett, Timothy H. 2008. The Woman who Discovered Printing. New Haven, Conn., London: Yale University Press.

2012. From Religious Ideology to Political Expediency in Early Printing: An Aspect of Buddho-Daoist Rivalry. London: Minnow Press.

Chartier, Roger. 2007. "The printing revolution: A reappraisal." In Agent of Change: Print Culture Studies after Elizabeth L. Eisenstein, edited by Sabrina Alcorn Baron, Eric N. Lindquist and Eleanor F. Shevlin, 397-408. Amherst: University of Massachusetts Press.

Fujieda, Akira. 1973. "The Tun-huang Manuscripts." In Essays on the Sources for Chinese History, edited by Donald D. Leslie, Colin Mackerras and Wang Gungwu, 120-128. Canberra: Australian National University Press. 
Galambos, Imre. 2011. “The Tangut translation of the General's Garden by Zhuge Liang." Pis'mennye Pamjatniki Vostoka 1 (14): 131-142.

2012. "Consistency in Tangut Translations of Chinese Military Texts." In Tanguty $v$ Tsentral'noj Azii: Sbornik stat'ej v chest' 8o-letija prof. E. I. Kychanova [Tanguts in Central Asia: a collection of articles marking the 8oth anniversary of Prof. E. I. Kychanov], edited by Irina Popova, 84-96. Moscow: Oriental Literature.

Grinstead, Eric. 1961. "Tangut fragments in the British Museum." The British Museum Quarterly 24.3/4: 82-87.

1972. Analysis of Tangut script. (Scandinavian Institute of Asian Studies Monograph Series 10). Lund: Studentlitteratur.

Heijdra, Martin and Cao Shuwen. 1992. "The world's earliest extant book printed from wooden movable type? Chüan seventy-seven of the Tangut translation of the Garland sutra." The Gest Library Journal 5.1: 70-89.

Imaeda Yoshiro. 2008. "The provenance and character of the Dunhuang documents." Memoirs of the Toyo Bunko 66: 81-102.

Kepping, Ksenija B. 1977. "Rukopisnyj fragment voennogo traktata Sun' Tszy v tangutskom perevode." Pis'mennye Pamjatniki Vostoka (1972): 161-166.

— 1979. Sun'-tszy v tangutskom perevode: Faksimile ksilografa, izdanie teksta, perevod [The Sunzi in Tangut translation: Facsimile of the woodblock prints, an edition of the text, and a translation]. Moscow: Nauka.

1985. Tangutskij jazyk: Morfologija [Tangut language: Morphology]. Moscow: Nauka.

Kepping, Ksenija B. and Anton P. Terent'ev-Katanskij. 1987. "Apokrif o Ljanskom U-di v tangutskom perevode" [An apocryphal text on Liang Wudi in Tangut translation]. Pis'mennye Pamjatniki Vostoka (1978-1979): 186-190.

Kepping, Ksenija B. and Gong Hwang-cherng. 2003. "Zhuge Liang's 'The General's Garden' in the Mi-nia Translation." In Poslednie stat'i i dokumenty, edited by Ksenija B. Kepping, 12-23. St. Petersburg: Omega.

Kolokolov, Vsevolod S. and Evgenij I. Kychanov. 1966. Kitajskaja klassika v tangutskom perevode: Lun'Juj, Men Tszy, Sjao Tszin [Chinese classics in Tangut translation: The Lunyu, Mengzi, Xiaojing]. Moscow: Nauka.

Kornicki, Peter. 2006. "Manuscript, not print: Scribal culture in the Edo period." Journal of Japanese Studies 32.1: 23-52.

Kozlov, Pjotr K. 1923. Mongolija i Amdo i Mertvyj Gorod Khara-khoto. Moscow: Nauka.

Kychanov, Evgenij I. 2005. "Jashmovoe zerkalo komandovanija vojskami let upravlenija Chen'-guan' (1101-1113): Vstupitel'naja stat'ja i perevod s tangutskogo” [The jasper mirror of commanding the troops from the Zhenguan reign (1101-1113): Introduction and translation of the Tangut text]. Pis'mennye Pamjatniki Vostoka (2005): 5-34.

Lin Yingjin 林英津. 1994. Xiayi Sunzi bingfa yanjiu 夏譯《孫子兵法》研究. Taipei: Institute of History and Philology, Academia Sinica. 
Mair, Victor H. 2008. "Soldierly Methods: Vade Mecum for an Iconoclastic Translation of Sun Zi bingfa, with a complete transcription and word-for-word glosses of the Manchu translation by H. T. Toh." Sino-Platonic Papers 178: 1-195.

Nie Hongyin 聶鴻音. 1991. “Xixia yi Sunzi zhuan kaoshi” 西夏譯《孫子傳》考釋. Zhongguo minzu guwenziyanjiu 中國民族古文字研究 3: 267-278.

Ningxia wenwu kaogu yanjiusuo 寧夏文物考古研究所. 2005. Baisigou Xixia fangta 拜寺溝西夏方塔. Beijing: Wenwu chubanshe.

Niu Dasheng 牛達生. 1994. "Woguo zuizao de muhuozi yinshuapin: Xixiawen fojing Jixiang bianzhi kouhe benxu” 我國最早的木活字印刷品 -- 西夏文 佛經〈吉祥遍至口和本續〉. Zhongguoyinshua 中國印刷 2.

Rong Xinjiang. 1999. "The nature of the Dunhuang library cave and the reasons for its sealing." Cahiers d'Extrême-Asie 11: 247-275.

Rong Xinjiang 榮新江. 2007. "E cang Dunhuang wenxian zhong de Heishuicheng wenxian” 〈俄藏敦煌文獻〉 中的黑水城文獻. In Heishuicheng renwenyu huanjing yanjiu 黑水城人文與環境研究, edited by Shen Weirong 沈衛榮, Nakao Masayoshi 中尾正義 and Shi Jinbo 史金波, 534-548. Beijing: Zhongguo renmin daxue chubanshe.

Xibei di'er minzu xueyuan 西北第二民族學院, Shanghai guji chubanshe 上海古籍出版社, and Yingguo guojia tushuguan 英國國家圖書館. 2005. Yingguo guojia tushuguan cang Heishuicheng wenxian 英國國家圖書館藏黑水城文獻. Shanghai: Shanghai guji chubanshe.

Shen Weirong 沈衛榮. 2007. "Xixiawen zangchuan xudian Jixiang bianzhi kouhe benxu yuanliu, miyi kaoshu (shang)” 西夏文藏傳續典《吉祥遍至口合本續》 源流、密意考述 (上). Xixiaxue 西夏學 2: 92-98.

Shi Jinbo 史金波 and Yasen Wushou'er 雅森.吾守爾 (Yasin Ashuri). 1999. Zhongguo huozi yinshuashu de faming he zaoqi chuanbo: Xixia he Huigu huozi yinshuashu yanjiu 中國活字印刷術的發明和早期傳播 - - 西夏和回鶻活字印刷術研究. Beijing: Shehui kexue wenxian chubanshe.

Sun Shouling 孫壽岭. 1994. “Xixia nihouziban fojing” 西夏泥活字版佛經. Zhongguo wenwubao 中國文物報 $(27$ March): 3 .

2007. "Why I reprinted the final portion of the Vimalakirti-Nirdeśa using movable type made of clay." Early Medieval China 13-14.1: 233-263. Translated by Adam D. Smith, annotated by Lothar von Falkenhausen.

SunYingxin孫穎新.2010. “XixiayibenSunzizhuankaobu”西夏譯本《孫子傳》考補. Xixiaxue 西夏學 6: 70-74.

van Schaik, Sam and Imre Galambos. 2012. Manuscripts and Travellers: The Sino-Tibetan Documents of a Tenth-century Buddhist Pilgrim. Berlin: de Gruyter.

Zhang Xiumin 張秀民. 2006. Zhongguoyinshuashi 中國印刷史. Hangzhou: Zhejiang guji chubanshe. Edited and supplemented by Han Qizeng 韓琦增. 